\title{
Long-term performance and microbial community analysis of a full-scale synthesis gas fed reactor treating sulfate- and zinc-rich wastewater
}

\author{
Bernd H. G. W. van Houten • Wim van Doesburg • \\ Henk Dijkman • Cris Copini • Hauke Smidt • \\ Alfons J. M. Stams
}

Received: 23 March 2009/Revised: 4 June 2009 / Accepted: 4 June 2009/Published online: 19 June 2009

(C) The Author(s) 2009. This article is published with open access at Springerlink.com

\begin{abstract}
The performance of a full-scale $\left(500 \mathrm{~m}^{3}\right)$ sulfidogenic synthesis gas fed gas-lift reactor treating metal- and sulfate-rich wastewater was investigated over a period of 128 weeks. After startup, the reactor had a high methanogenic activity of $46 \mathrm{Nm}^{3} \cdot \mathrm{h}^{-1}$. Lowering the carbon dioxide feed rate during the first 6 weeks gradually lowered the methane production rate. Between weeks 8 and 93, less than $1 \%$ of the hydrogen supplied was used for methanogenesis. Denaturing gradient gel electrophoresis analysis of polymerase chain reaction-amplified 16S rRNA gene fragments showed that the archaeal community decreased in diversity but did not disappear completely. After the carbon dioxide feed rate increased in week 88 , the methane production rate also increased, confirming that methane production was carbon dioxide limited. Even though lowering the carbon dioxide feed appeared to affect part
\end{abstract}

B. H. G. W. van Houten - W. van Doesburg $\cdot$ H. Smidt

A. J. M. Stams $(\bowtie)$

Laboratory of Microbiology,

Dreijenplein 10,

6703 HB Wageningen, The Netherlands

e-mail: Fons.stams@wur.nl

H. Dijkman

Paques B.V.,

T. de Boerstraat 24, P.O. Box 52, 8560 AB Balk, The Netherlands

C. Copini

Nyrstar Budel Zink B.V.,

P.O. Box 2001, 6020 AA Budel, The Netherlands

Present Address:

B. H. G. W. van Houten

Institute of Biological Environmental and Rural Sciences,

Aberystwyth University,

Plas Gogerddan,

Aberystwyth, Ceredigion SY23 3EB, UK of the sulfate-reducing community, it did not prevent achieving the desired rates of sulfate reduction. The average sulfate conversion rate was $181 \mathrm{~kg} \cdot \mathrm{h}^{-1}$ for the first 92 weeks. After 92 weeks, the sulfate input rate was increased and from week 94 to 128 , the average weekly sulfate conversion rate was $295 \mathrm{~kg} \cdot \mathrm{h}^{-1}(\mathrm{SD} \pm 87)$. Even higher sulfate conversion rates of up to $400 \mathrm{~kg} \cdot \mathrm{h}^{-1}$ could be sustained for weeks 120 128. The long-term performance and stability together with the ability to control methanogenesis demonstrates that synthesis gas fed reactor can be used successfully at full scale to treat metal and sulfate-rich wastewater.

Keywords Sulfate reduction - Methanogenesis · Hydrogen Bioremediation $\cdot$ Metals $\cdot$ Community analysis

\section{Introduction}

Sulfate- and metal-rich wastewaters that are low in organic carbon are produced as a result of several industrial activities, such as metal smelting, flue gas scrubbing, and mining. Sulfate-reducing bioreactors have been shown to be suitable systems to remediate these types of wastewater (Boonstra et al. 1999). These bioreactors utilize the sulfidogenic activity of sulfate-reducing bacteria (SRB) to simultaneously remove sulfate and metals in the form of metal sulfides (Muyzer and Stams 2008).

Paques B.V. (Balk, The Netherlands) has developed a sulfidogenic SULFATEQ ${ }^{\circledR}$ system, which is based on a gaslift reactor fed with hydrogen gas as the electron donor for sulfate reduction. For large-scale applications, synthesis gas is an attractive source of hydrogen (van Houten and Lettinga 1994). Synthesis gas composition varies depending on the organic carbon source used for its production, but it 
contains mainly $\mathrm{H}_{2}, \mathrm{CO}_{2}$, and $\mathrm{CO}$ with minor levels of other components, such as methane and nitrogen. After tests conducted at pilot-scale, the first full-scale synthesis gas fed reactor was constructed to treat wastewater from the Nyrstar Budel Zink zinc smelting plant (Budel-Dorplein, The Netherlands). The full-scale sulfidogenic bioreactor was chosen over the original lime stone neutralization process because the zinc sulfide produced in the bioreactor is suitable to be re-used as a zinc ore in the zinc smelting process. As a consequence, no solid waste is produced. Furthermore, since the solubilities of most metal sulfides are much lower than those of their respective hydroxides, considerably lower effluent metal concentrations can be achieved.

During startup the full-scale reactor was fed with purified synthesis gas containing mainly hydrogen (van Houten et al. 2006). While startup of the reactor was successful and the desired rate of sulfate reduction was achieved, hydrogenotrophic methanogenesis was not suppressed despite the predominance of SRB (van Houten et al. 2006). Methanogenesis is an unwanted process, as it increases operational costs. Persistence of methanogenesis was unexpected, as prior research had shown suppression of methanogenesis by sulfate reduction in lab-scale systems (van Houten et al. 1994; Weijma et al. 2002). The suppression of methanogenesis by sulfate reduction in anaerobic bioreactors is often attributed to the fact that SRB can reach much lower hydrogen threshold concentrations compared to methanogens. Based on the hydrogen thresholds of the methanogens and SRB detected within the sludge (van Houten et al. 2006), methanogenesis should have been suppressed rapidly by sulfate reduction. However, because of the relatively short sludge retention time (SRT) of 4-7 days employed for the full-scale reactor, hydrogen threshold concentrations cannot be reached. During operation at full scale, process conditions fluctuate and mass transfer of hydrogen to the liquid phase exceeds the requirement for sulfate reduction for the majority of time. Consequently, a continuous state of hydrogen limitation is not reached, and as a result, methanogens are not readily outcompeted by SRB.

A potential strategy to suppress methanogenesis would be to limit the carbon dioxide feed to the reactor. As hydrogenotrophic methanogens require carbon dioxide as their terminal electron acceptor, limiting the carbon dioxide feed should lower their activity. SRB also require carbon dioxide for growth but only as source of carbon. Heterotrophic SRB were found to be the predominant microorganisms in the reactor (van Houten et al. 2006). These SRB utilize carbon dioxide as a carbon source but only to a minor extent, as they obtain most of their carbon (Sorokin 1966a,b; Badziong and Thauer 1979) from the organic carbon source provided.

Information on the long-term performance and the microbial community composition and dynamics is still very limited for this type of bioreactor, especially at full scale. Additional information, especially on community dynamics in relation to operational changes, may provide information that can be used to understand how to consequently control the performance of synthesis gas fed bioreactors. Therefore, we have studied the performance based on sulfate reduction rates and monitored methane production over a prolonged period of 128 weeks. During this period, the carbon dioxide feed to the reactor was lowered. For the same period the composition and dynamics of the dominant bacterial and archaeal species was studied. Temporal community changes were assessed using denaturing gradient gel electrophoresis (DGGE), while the relative abundance and identity of dominant bacterial species in the sludge were estimated using restriction fragment length polymorphism (RFLP) and sequence analysis of $16 \mathrm{~S}$ rRNA gene clone libraries.

\section{Materials and methods}

\section{Reactor operating conditions}

The reactor was a $500-\mathrm{m}^{3}$ full-scale gas-lift reactor treating sulfate and heavy metal-rich wastewater from a zinc smelter in Budel-Dorplein, The Netherlands. A schematic flow diagram and operating conditions have been presented previously (van Houten et al. 2006). A waste stream consisting of a mix of sulfate-rich waste acid neutralized with zinc oxide produced during the zinc production process was fed to the reactor. The main pollutants in the reactor feed were sulfate $(5-30 \mathrm{~g} / \mathrm{L})$, zinc $(3-15 \mathrm{~g} / \mathrm{L})$, and magnesium (30-500 mg/L). Hydrogen was supplied as the electron donor for sulfate reduction in the form of purified synthesis gas. Additionally small amounts of urea, phosphoric acid, and acetate were added as nitrogen, phosphate, and carbon source. The reactor was operated between $30^{\circ} \mathrm{C}$ and $35^{\circ} \mathrm{C}$ and $\mathrm{pH} 7.0$ and 7.5. The SRT varied between 4 and 7 days. The hydraulic retention time varied between 1 and 3 days.

Reactor performance monitoring and chemical analyses

Sulfate concentrations of the influent and effluent were measured using ion chromatography and hydrogen, methane, and carbon dioxide concentrations of the reactor feed, bleed, and recycle gas were measured by gas chromatography as previously described (van Houten et al. 2006).

Nucleic acids isolation and PCR

Sludge samples for nucleic acid isolation were taken from the sludge recycle. Samples $(6 \mathrm{ml})$ were fixed with $9.5 \mathrm{ml}$ ethanol and $0.5 \mathrm{ml} 0.8 \mathrm{M}$ sodium chloride prior to storage at $-20^{\circ} \mathrm{C}$. 
Total DNA was extracted as previously described (Oude Elferink et al. 1997). 16S rRNA genes were polymerase chain reaction (PCR) amplified from the sludge DNA extract using a Taq DNA polymerase kit (Life Technologies, Gaithersburg, MD, USA). All primers were purchased from MWG-Biotech (Ebersberg, Germany). Bacterial 16S rRNA genes were selectively amplified for clone library construction and sequence analysis using 7-f and 1510-r primers (Lane 1991) with the following thermocycler program: $94^{\circ} \mathrm{C}$ for $5 \mathrm{~min} ; 25$ cycles of $94^{\circ} \mathrm{C}$ for $30 \mathrm{~s}, 52^{\circ} \mathrm{C}$ for $20 \mathrm{~s}$, and $68^{\circ} \mathrm{C}$ for $40 \mathrm{~s}$; and $68^{\circ} \mathrm{C}$ for $7 \mathrm{~min}$. For DGGE, partial bacterial 16S rRNA gene fragments were amplified using 968-GC-f and 1401-r primers (Nübel et al. 1996) with the same thermocycler program, but an increased number of 35 cycles and an annealing temperature of $56^{\circ} \mathrm{C}$ were used. For archaeal DGGE analyses, A109 (T)-f (original; Großkopf et al. 1998), third base pair changed into (T), and 515-GC-r (Lane 1991) were used for amplification. Reactions were performed with the following thermocycler program: $94^{\circ} \mathrm{C}$ for $5 \mathrm{~min} ; 35$ cycles of $94^{\circ} \mathrm{C}$ for $30 \mathrm{~s}$, $52^{\circ} \mathrm{C}$ for $40 \mathrm{~s}, 68^{\circ} \mathrm{C}$ for $1 \mathrm{~min}$, and $68^{\circ} \mathrm{C}$ for $7 \mathrm{~min}$. Amplification and size of PCR products were verified by $1 \%(w / v)$ agarose gel electrophoresis with ethidium bromide staining and comparison of amplification products to a 100bp DNA ladder (MBI Fermentas, Vilnius, Lithuania).

\section{DGGE and RFLP analysis}

DGGE analysis was performed on $8 \%(w / v)$ polyacrylamide gels containing a denaturing gradient of $35-60 \%$ for bacterial amplicons and 30-45\% for archaeal amplicons. One hundred percent denaturant corresponded to $7 \mathrm{M}$ urea and $40 \%(v / v)$ formamide. Electrophoresis was performed in $0.5 \times$ TAE buffer $(20 \mathrm{mM}$ Tris, $10 \mathrm{mM}$ acetic acid, and $0.5 \mathrm{mM}$ EDTA, pH8) at $85 \mathrm{~V}$ and $60^{\circ} \mathrm{C}$ for $16 \mathrm{~h}$ (after $10 \mathrm{~min}$ at $200 \mathrm{~V}$ ) using a DCode System (BioRad, Hercules, CA, USA). Gels were silver stained as described previously (Sanguinetti et al. 1994).

For the generation of bacterial clone libraries, amplified full-length 16S rRNA genes were purified using a QIAquick Kit (Qiagen GmbH, Hilden, Germany) and cloned into Escherichia coli JM109 by using the pGEM $^{\circledR}-\mathrm{T}$ Easy vector system (Promega, Leiden, The Netherlands). Clone libraries (96 clones for weeks 10 and 50 and 48 clones for week 128) were screened for number and relative abundance of unique clone types by RFLP analysis (digestion with $M s p \mathrm{I}, C f o \mathrm{I}$, and AluI, Invitrogen) and DGGE. Plasmids of selected transformants were then purified using the QIAprep spin miniprep kit (Qiagen GmbH, Hilden, Germany).

Sequence determination and analysis

16S rRNA gene-targeted sequence determination was carried out with the Sequenase sequencing kit (Amersham,
Slough, UK) using pGEM $^{\circledR}$-T vector-targeted sequencing primers Sp6 (5'-GATTTAGGTGACACTATAG-3') and T7 (5'-TAATACGACTCACTATAGGG-3') and internal primers Uni-533-forw (5'-GTGCCAGC(A/C)GCCGCGGTAA-3'), Bact-1100-rev (5'-GGGTTGCGCTCGTTG-3'). All primers were labeled with IRD800 (MWG-Biotech, Ebersberg, Germany). The sequences were automatically analyzed on a LI-COR (Lincoln, NE, USA) DNA sequencer 4000L. Sequences were checked for chimera using PINTAIL software (Ashelford et al. 2005) searched against the NCBI database using BLAST (http://www.ncbi.nlm.nih.gov/blast/) (McGinnis and Madden 2004). Alignment and phylogenetic analysis of 16S rRNA gene sequences were performed using the ARB software package and the latest release of the ARB-SILVA reference database (Ludwig et al. 2004; Pruesse et al. 2007). Phylogenetic analysis was performed using the neighbor joining method with Felsenstein correction as implemented in the ARB software package (Saitou and Nei 1987). The tree was constructed using E. coli positions 37-1461, using a general bacterial $50 \%$ conservation filter provided with the latest release of the ARB-SILVA database. Sequences generated from this work are deposited at GenBank under accession numbers DQ447163-DQ447176.

\section{Results}

\section{Reactor performance}

The sulfate input and output rates of the $500 \mathrm{~m}^{3}$ full-scale reactor were monitored for 128 weeks (Fig. 1). During operation, the sulfate input rate fluctuated as a result of the rates at which the influents were produced. Other causes for periods with lower or no sulfate reduction include a calamity in week 4 where the reactor was exposed to an unknown free zinc concentration, which affected the sulfate conversion rate. The reactor was taken offline in weeks 76 , 85 , and 99 for inspection and maintenance.

For the first 75 weeks, the weekly sulfate conversion rate was on average $201 \mathrm{~kg} \cdot \mathrm{h}^{-1}(\mathrm{SD} \pm 68)$. After 92 weeks, the average sulfate input rate increased due to changes in the composition of the wastewater. The reactor was able to accommodate this increased sulfate input rate, and from week 94 to 128 , the average weekly sulfate conversion rate was $295 \mathrm{~kg} \cdot \mathrm{h}^{-1}(\mathrm{SD} \pm 87)$. Even higher sulfate conversion rates of up to $400 \mathrm{~kg} \mathrm{~h}^{-1}$ could be sustained for weeks 120 128 weeks (Fig. 1).

The methane production rate and carbon dioxide feed rate were also monitored intermittently for 128 weeks (Fig. 2). Before the carbon dioxide feed rate was lowered, the reactor had a high methanogenic activity of $46 \mathrm{Nm}^{3} \cdot \mathrm{h}^{-1}$ (normal cubic meter, $T=293 \mathrm{~K}, p=101.325 \mathrm{~Pa}$ ). The carbon dioxide concentration in the feed gas was gradually lowered 


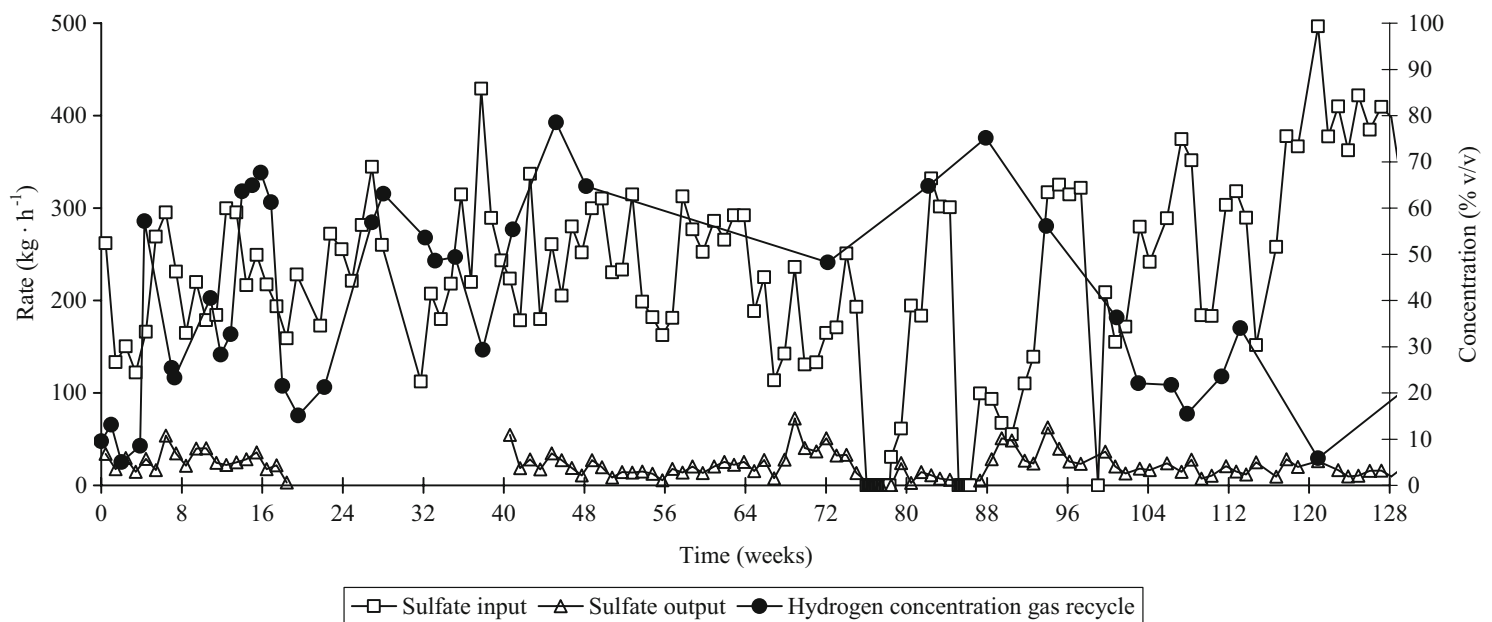

Fig. 1 Averaged weekly sulfate input and output rate and the hydrogen concentration in gas recycle of the Budel full-scale reactor

from $20-22 \%$ to $3-6 \%(v / v)$ during the first 4 weeks, resulting in a lowered carbon dioxide feed rate of $15-$ $20 \mathrm{Nm}^{3} \cdot \mathrm{h}^{-1}$. From week 6 onwards, the carbon dioxide feed rate was kept below $15 \mathrm{Nm}^{3} \cdot \mathrm{h}^{-1}$, and by week 8 , the methanogenic activity had decreased to $3 \mathrm{Nm}^{3}$ methane per hour. Between weeks 8 and 93, at an average hydrogen consumption rate of $2 \mathrm{Nm}^{3} \cdot \mathrm{h}^{-1}$, less than $1 \%$ of the hydrogen supply was used for methanogenesis. From week 88 , the feed gas carbon dioxide concentration varied between $3.4 \%$ and $10.2 \%$, due to a problem with the gas absorber used for carbon dioxide removal from the feed gas. This caused an increased feed of carbon dioxide to the reactor (Fig. 2). After a period of little methane production, an increase in methane production was detected from week 93 onwards. Methane production gradually increased, and based on an average hydrogen consumption rate of $132 \mathrm{Nm}^{3} \cdot \mathrm{h}^{-1}$ in week 103, approximately $25 \%$ of the supplied hydrogen was used for methanogenesis.
Archaeal community dynamics

To assess the influence of the changes in operating conditions on the archaeal community structure, 16S rRNA gene-targeted DGGE profiles were generated (Fig. 3). After the carbon dioxide feed rate had been lowered initially, the archaeal profiles gradually changed to a consistent profile consisting of two bands up to week 128. These results indicate that the lowered carbon dioxide feed decreased the archaeal diversity as observed by DGGE. Nevertheless, archaea were not completely removed from the system, as PCR amplification of archaeal 16S rRNA gene fragments was achieved for all samples. After the rate of methanogenesis increased again in week 93, no change in diversity was detected. The migration pattern of the archaeal clones obtained in our previous study (van Houten et al. 2006) was compared to the profiles obtained here. The migration pattern of the lower band matched that of clone BKV25 (GenBank accession number AY831647) and the top band
Fig. 2 Methane production rate and carbon dioxide feed rate of the Budel full-scale reactor, volume is given in normal cubic meter $(T=293 \mathrm{~K}$, $p=101.325 \mathrm{~Pa})$

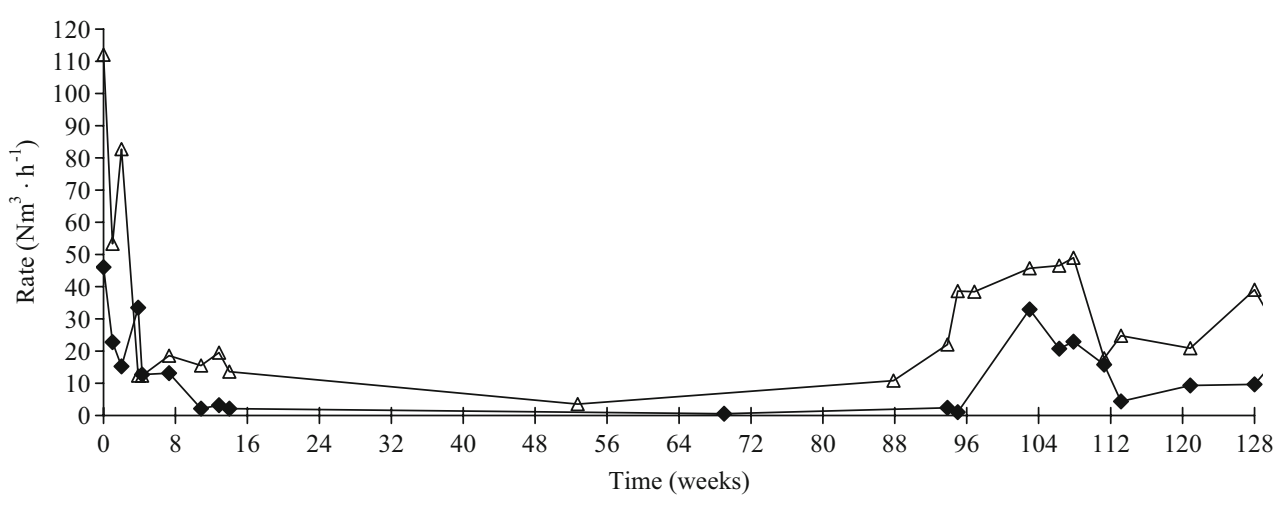

Methane production rate $\triangle$ Carbon dioxide feed rate 


\section{-m으유}

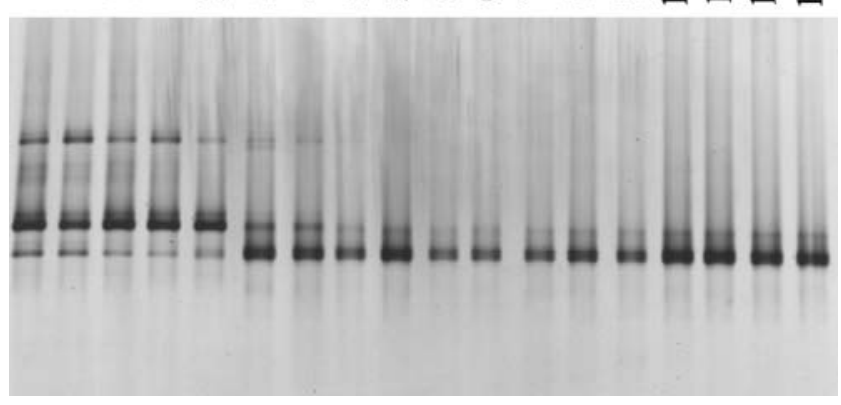

Fig. 3 Analysis of archaeal community dynamics by 16S rRNA genetargeted PCR-DGGE. Numbers indicate week of sampling

that of clone BKV18 (AY831642). Both of these clones represent populations belonging to the genus Methanobacterium based on partial 16S rRNA gene analysis.

\section{Bacterial community dynamics}

The temporal dynamics of the bacterial community were also monitored for the complete period of 128 weeks using DGGE (Fig. 4). After consecutive changes up to week 41, the community structure became relatively stable between week 41 and 101 with four pre-dominant bands. This period was characterized by a stable operation of the reactor with only minor fluctuations in the sulfate input rate, the hydrogen concentration in the gas recycle (Fig. 1), and the feed gas rate and composition (data not shown). After week 101 , a shift in the bacterial community to one dominant band (A) was observed.

16S rRNA gene clone libraries were constructed for the bacterial community from samples taken in weeks 10,50 , and 128 (Table 1). Only abundant operational taxonomic units with unique RFLP and DGGE migration patterns and represented by two or more clones were further characterized by sequence analysis of representative clones. The dominance $(82.6 \%)$ of two clones belonging to the genus Desulfomicrobium found previously (van Houten et al. 2006) was not found in week 10 , even though there were only 6 weeks between these time points. The RFLP data for week 10 showed a relative abundance of only $6 \%$ for clone BUD03 that belonged to the genus Desulfomicrobium. A large number of abundant clones from week 10 and also week 50 did not belong to known genera of SRB. For instance, phylogenetic analysis (Fig. 5) showed that clone BUD01 and BUD07 belonged to the phylum Bacteroidetes. Clone BUD04 from week 10 and clones BUD13, BUD09, and BUD14 from later time points, cluster within the Chloroflexi subphylum I (Fig. 5), as defined by Hugenholtz et al. (1998).

The low bacterial diversity observed in the clone library of week 128 is in agreement with the reduction in diversity observed by DGGE after week 101. In week 128, the microorganisms represented by clone BUD16 appear to be predominant as indicated by RFLP abundance $(27.7 \%)$. Clone BUD16 showed the highest level of sequence identity (95\%) to the sulfate reducer Desulfovibrio giganteus. The highly related clone BUD15 (Fig. 5) also showed a high relative abundance $(21.3 \%)$. The migration pattern of clone BUD15 on DGGE was the same as predominant band A observed in the DGGE profiles from weeks 111, 121, and 128. The migration pattern of BUD 16 did not match any of the dominant bands in the community profile. However, sequence analysis showed one base pair difference in the amplification range of primer 968-GC-f and 1401-r between BUD15 and BUD16. This may have prevented clone BUD16 to come up as a clear band in the community profile.

A large number of RFLP patterns were found that were represented by single clones: $59.7 \%, 27 \%$, and $47 \%$ for weeks 10, 50, and 128, respectively. An unknown number of these unique clones are likely to be sulfate reducers considering the high rates of sulfate reduction observed. The diversity and abundance of species that did not belong to that of known SRB found within the clone libraries (Table 1) was not completely reflected by the results obtained by DGGE. The universal primer 968-GC-f and 1401-r for DGGE showed two mismatches with clones BUD04, BUD07, BUD09, BUD13, and BUD14 and three mismatches with clones BUD05, BUD10, and BUD12, resulting in a poor or no amplification of the individual clones (data not shown).
Fig. 4 Analysis of bacterial community dynamics by $16 \mathrm{~S}$ rRNA gene-targeted PCRDGGE. Numbers indicate week of sampling. Band positions A, $\mathrm{B}$, and $\mathrm{C}$ correspond with library clones BUD16, BUD03, and BUD11, respectively. Band position B corresponds to that of Desulfovibrio paquesii strain SB1
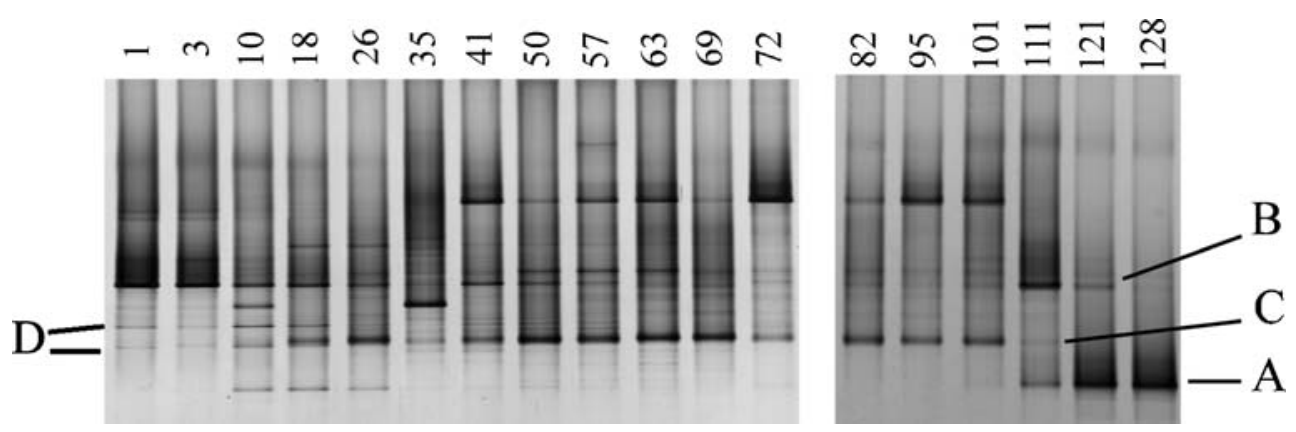
Table 1 Relative abundance and closest relatives of cloned bacterial 16S rRNA gene sequences obtained from weeks 10, 50, and 128 based on sequence analysis of the 16S rRNA gene

\begin{tabular}{|c|c|c|c|c|c|c|}
\hline Week & Clone & $\begin{array}{l}\text { GenBank } \\
\text { accession number }\end{array}$ & $\begin{array}{l}\text { Relative } \\
\text { abundance (\%) }\end{array}$ & Closest relative & $\begin{array}{l}\text { GenBank } \\
\text { accession } \mathrm{nr}\end{array}$ & $\begin{array}{l}\text { Identities } \\
(\%)\end{array}$ \\
\hline \multirow[t]{6}{*}{10} & BUD05 & DQ447166 & 13.4 & $\begin{array}{l}\text { Uncultured Thermotogales bacterium } \\
\text { clone Er-MLAYS-35 }\end{array}$ & EU542473 & 98 \\
\hline & BUD10 & DQ447170 & 9.0 & $\begin{array}{l}\text { Uncultured Thermotogales bacterium } \\
\text { clone Er-LLAYS-110 }\end{array}$ & EU542543 & 99 \\
\hline & BUD03 & DQ447164 & 6.0 & $\begin{array}{l}\text { Uncultured Desulfomicrobium } \\
\text { bacterium mle1-31 }\end{array}$ & AF280859 & 99 \\
\hline & BUD04 & DQ447165 & 4.5 & $\begin{array}{l}\text { Uncultured Chloroflexi bacterium } \\
\text { clone Er-LLAYS-45 }\end{array}$ & EU542508 & 98 \\
\hline & BUD01 & DQ447163 & 4.5 & $\begin{array}{l}\text { Uncultured Bacteroidetes group } \\
\text { bacterium clone D25_22 }\end{array}$ & EU266899 & 96 \\
\hline & Unidentified clones & & 62.7 & & & \\
\hline \multirow[t]{8}{*}{50} & BUD13 & DQ447173 & 14.7 & $\begin{array}{l}\text { Uncultured Chloroflexi bacterium } \\
\text { clone D22-814 }\end{array}$ & EF174247 & 99 \\
\hline & BUD11 & DQ447171 & 11.6 & $\begin{array}{l}\text { Uncultured Desulfovibrio bacterium } \\
\text { clone E14 }\end{array}$ & AY426458 & 98 \\
\hline & BUD10 & DQ44717 & 11.6 & $\begin{array}{l}\text { Uncultured Thermotogales bacterium } \\
\text { clone Er-LLAYS-110 }\end{array}$ & EU542543 & 99 \\
\hline & BUD07 & DQ447167 & 10.5 & $\begin{array}{l}\text { Uncultured Bacteroidetes group } \\
\text { bacterium clone D25_22 }\end{array}$ & EU266899 & 96 \\
\hline & BUD12 & DQ447172 & 9.5 & $\begin{array}{l}\text { Uncultured Thermotogales bacterium } \\
\text { clone Er-LLAYS-110 }\end{array}$ & EU542543 & 99 \\
\hline & BUD09 & DQ447169 & 7.4 & $\begin{array}{l}\text { Uncultured Chloroflexi bacterium } \\
\text { clone D22-814 }\end{array}$ & EF174247 & 99 \\
\hline & BUD08 & DQ447168 & 4.2 & $\begin{array}{l}\text { Uncultured Desulfovibrio bacterium } \\
\text { clone E14 }\end{array}$ & AY426458 & 98 \\
\hline & Unidentified clones & & 30.6 & & & \\
\hline \multirow[t]{4}{*}{138} & BUD16 & DQ447176 & 27.7 & Desulfovibrio giganteus & AF418170 & 95 \\
\hline & BUD15 & DQ447175 & 21.3 & Desulfovibrio giganteus & AF418170 & 95 \\
\hline & BUD14 & DQ447174 & 4.3 & $\begin{array}{l}\text { Uncultured Chloroflexi bacterium } \\
\text { clone Er-LLAYS- } 45\end{array}$ & EU542508 & 99 \\
\hline & Unidentified clones & & 46.8 & & & \\
\hline
\end{tabular}

Closest relatives were found by comparison of the sequences against those deposited in the GenBank datbase using BLAST (analysis performed January 2009). Relative abundance was calculated based on the number of similar clones found by RFLP analysis for each individual sludge sample

\section{Discussion}

The community analysis results clearly show that even a mainly hydrogen fed sulfate-reducing bioreactor can sustain a diverse bacterial community not restricted to just hydrogenotrophic SRB. The notable presence and potential role of Bacteriodetes, Chloroflexi, and even Thermotogales in a mesophilic reactor community, which was fed with limited amounts of acetate as the only organic carbon and hydrogen as the main electron donor is intriguing. Even though these phyla are underrepresented when it comes to cultured and described species, these organisms appear to be generally involved in degradation of carbohydrates and proteins. For instance, the closest physiologically characterized relative to Bacteriodetes clones, Proteiniphilum acetatigenes strain TB107 UNI-1T, has been shown to grow on complex substrates such as sugars and amino acids but not on hydrogen. Okabe et al. (2005) presented data that strongly suggest that members of the Chloroflexi preferentially utilize microbial products derived from biomass decay. As the ingoing wastewater did not contain complex organic compounds, a plausible explanation for their presence would be that these organisms are involved in the degradation of microbial cell material in sludge. Under normal conditions, due to the relatively high growth rate in the reactors (estimated doubling time of $0.14-0.25$ day $^{-1}$ based on SRT), there will be a continuous production of dead cells allowing these putative scavengers to persist in the system.

Koizumi and co-workers have observed coexistence of SRB and Chloroflexi in the top sediment of a saline meromictic lake (Koizumi et al. 2004). They proposed a syntrophic relationship between SRB and Chloroflexi, where members of subphylum I might be initial degraders of macromolecules, providing fatty acids and hydrogen as electron donors for SRB. If this interaction also takes place 


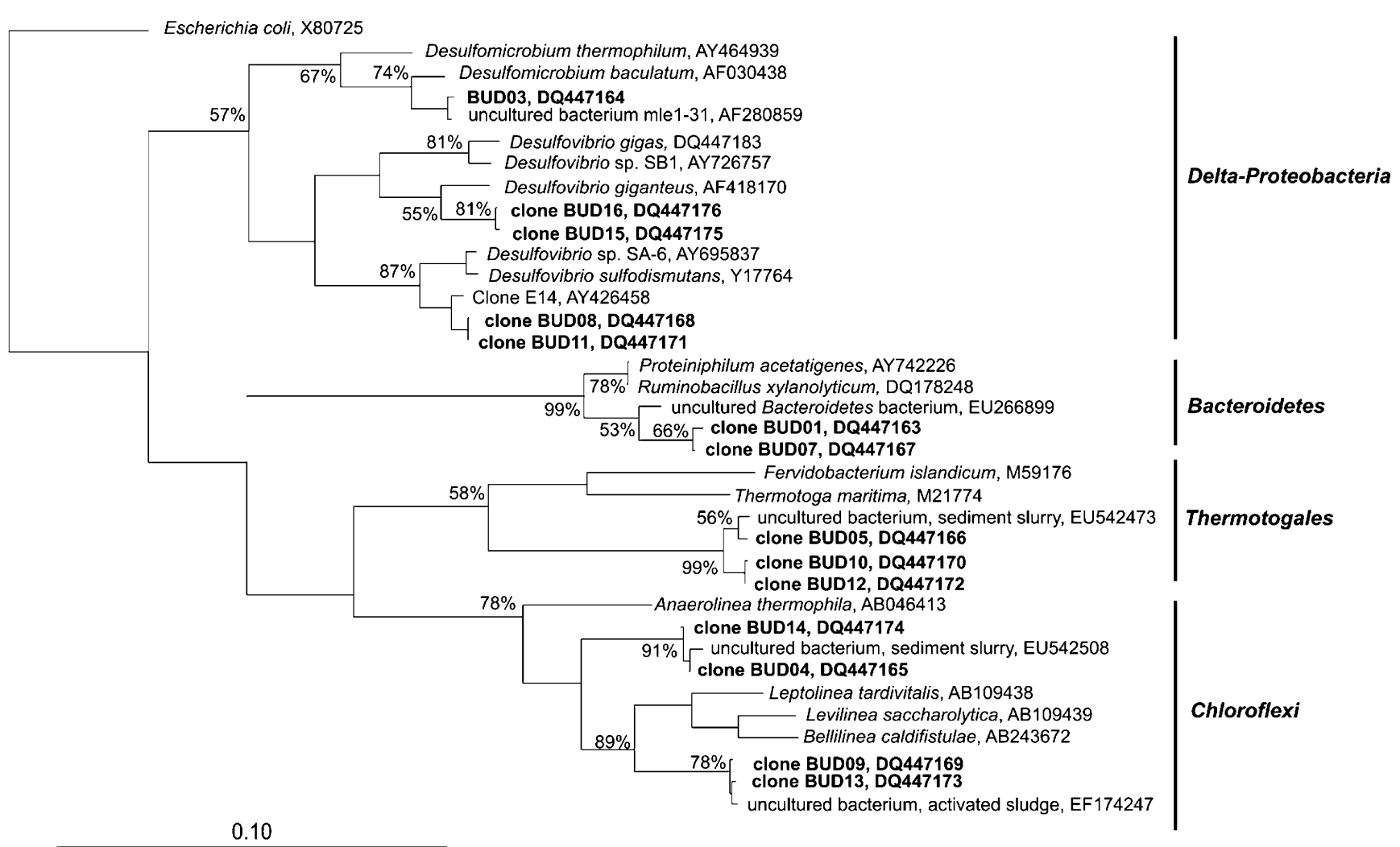

Fig. 5 Phylogenetic tree of 16S rRNA gene sequences retrieved from the full-scale reactor at weeks 10, 50, and 128, and reference sequences. Accession numbers are indicated. The scale bar indicates the branch length that represents $10 \%$ sequence dissimilarity. The tree was constructed using the neighbor-joining algorithm as implemented in ARB (Ludwig et al. 2004). Bootstrapping was performed with 1,000 replications, and only values above $50 \%$ are indicated

the hydrogen concentration of the recycle gas was low during this period, it is highly unlikely that this shift was caused by hydrogen limitation considering the high methanogenic activity in the same period. If a continuous state of hydrogen limitation had occurred, methanogenesis should have suppressed rapidly by sulfate reduction (Schönheit et al. 1982). A much more plausible explanation would be that growth of BUD15 and BUD16 had been carbon limited, more specifically carbon dioxide limited. Band A was visible throughout the whole monitored period. It was also more predominant in weeks $10-26$ but gradually became less so following the gradually lowered carbon dioxide feed rate. The increased carbon dioxide feed rate from week 96 would have alleviated this limitation allowing it to become more abundant. This would imply that the microorganisms represented by the D. giganteus like clones BUD16 and BUD15 possess a high growth rate $\left(\mu_{\max }\right)$ on and possibly a higher affinity $\left(K_{\mathrm{m}}\right)$ for hydrogen, giving them a selective advantage over other SRB when carbon dioxide is not growth limiting. This observation of potential carbon dioxide limitation affecting part of the SRB community may also explain in part why the two clones belonging to the genus Desulfomicrobium found to be dominant during startup (van Houten et al. 2006) became less dominant abundance, $27.7 \%$ and $21.3 \%$ respectively. Even though 
during the first 10 weeks of gradually lowering the carbon dioxide feed to the reactor. In addition, the calamity in week 4, where too much metal-rich waste water was fed to the reactor-causing metal toxicity would also have impacted their relative abundance.

Desulfovibrio paquesii strain SB1 (van Houten et al. 2009) was isolated from the Budel full-scale reactor from a sample taken in week 7. It was found to be one of the dominant SRB at that time based on a MPN dilution counts. The DGGE migration pattern of strain SB1 consisting of the two bands indicating D (Fig. 4) is visible up to week 18. It was found that strain SB1 has a relatively high maximum growth rate of 1.9-2.8 day $^{-1}$, which may explain its abundance at the time of isolation (van Houten 2006) shortly after the calamity. Its gradual decline in abundance thereafter based on DGGE analysis may also have been due to carbon dioxide limitation with the SRB community gradually shifting toward populations better adapted to the prevailing low carbon dioxide concentrations.

The observed redundancy within the SRB present in the reactor could be an important factor in maintaining a stable prolonged reactor performance under fluctuating process conditions. Based on prevailing conditions, only a limited number of SRB will become abundant and contribute to the reactors performance. In addition, Kaksonen et al. (2004) demonstrated that two lab-scale sulfate-reducing fluidized bed reactor communities, enriched and maintained on a single electron donor treating acidic metal-containing wastewater, were composed of a diverse mixture of bacteria including several SRB. This diversity and flexibility of microbial communities were also suggested to enhance the robustness of the reactor under varying operational conditions.

Lowering the carbon dioxide feed resulted in a clear decrease in methanogenic activity to the extent that less than $1 \%$ of the hydrogen supplied was used for methanogenesis between week 8 and 93. Lowering the carbon dioxide feed also decreased the archaeal diversity observed by DGGE. The lowered methanogenic activity suggests that carbon dioxide became the growth-limiting substrate for methanogenic archaea. In addition, the competition for a single growth-limiting substrate could be expected to decrease diversity. The increase in the rate of methanogenesis after the carbon dioxide feed had increased from week 88 onwards confirms that the archaeal community was carbon dioxide limited between week 13 and 95. Hence, limiting the carbon dioxide feed proved to be an effective tool to control the methanogenic activity, but it did not result in a complete washout of methanogens from the reactor. Consequently the reactor remained vulnerable to an increased methanogenic activity after the carbon dioxide feed rate increased. These results demonstrate clearly that it is crucial to tightly control the carbon dioxide feed during operation of synthesis gas fed reactors to minimize methanogenesis.
In summary, this study demonstrates that full-scale synthesis gas fed reactors fed with hydrogen as the main electron donor can sustain a relatively diverse microbial community that is not restricted to sulfate-reducing bacteria. During operation at full scale, fluctuations in process conditions enabled multiple populations of hydrogenotropic SRB to co-exist. Lowering the carbon dioxide feed proved to be an effective tool to control the methanogenic activity. It also resulted in lowering the archaeal diversity, but it did not result in a complete washout of methanogens from the reactor. In addition, it appeared to affect part of the sulfatereducing community, but it did not impact the diversity in the same way or prevented achieving the desired rates of sulfate reduction. This, together with the ability to minimize methanogenesis, demonstrates that synthesis gas fed sulfidogenic bioreactors can be used successfully at full scale to treat metal and sulfate-rich wastewater.

Acknowledgments This research was supported by a grant from the E.E.T. program of the Dutch ministries of Economic Affairs, Education, Culture and Sciences and Housing, Spatial Planning, and the Environment (EETK98028). We would like to thank W. Vermeulen at Nyrstar Budel Zink for his help and valuable discussion.

Open Access This article is distributed under the terms of the Creative Commons Attribution Noncommercial License which permits any noncommercial use, distribution, and reproduction in any medium, provided the original author(s) and source are credited.

\section{References}

Ashelford KE, Chuzhanova NA, Fry JC, Jones AJ, Weightman AJ (2005) At least 1 in 20 16S rRNA sequence records currently held in public repositories is estimated to contain substantial anomalies. Appl Environ Microbiol 71:7724-7736

Badziong W, Thauer RK (1979) Acetate and carbon dioxide assimilation in Desulfovibrio vulgaris (Marburg) growing on hydrogen plus sulfate as sole energy source. Arch Microbiol 123:167-189

Boonstra J, van Lier J, Janssen G, Dijkman H, Buisman CJN (1999) Biological treatment of acid mine drainage. In: Amils R, Ballister A (eds) Biohydrometallurgy and environment toward the 21st century. Process metallurgy 9B. Elsevier, Amsterdam, pp 559567

Großkopf R, Janssen PH, Liesack W (1998) Diversity and structure of the methanogenic community in anoxic rice paddy soil microcosms as examined by cultivation and direct $16 \mathrm{~S}$ rRNA gene sequence retrieval. Appl Environ Microbiol 64:960-969

Hugenholtz P, Pitulle C, Hershberger KL, Pace NR (1998) Novel division level of bacterial diversity in a Yellowstone hot spring. $\mathrm{J}$ Bacteriol 180:366-376

Kaksonen AH, Plumb JJ, Franzmann PD, Puhakka JA (2004) Simple organic electron donors support diverse sulfate-reducing communities in fluidized-bed reactors treating acidic metal- and sulfate-containing wastewater. FEMS Microbiol Ecol 47:279289

Koizumi Y, Kojima H, Fukui M (2004) Dominant microbial composition and its vertical distribution in saline meromictic Lake Kaiike (Japan) as revealed by quantitative oligonucleotide 
probe membrane hybridization. Appl Environ Microbiol 70:4930-4940

Lane DJ (1991) 16S/23S rRNA sequencing. In: Stackebrandt E, Goodfellow M (eds) Nucleic acid techniques in bacterial systematics. Wiley, New York, pp 115-175

Ludwig W, Strunk O, Westram R, Richter L, Meier H, Yadhukumar BA, Lai T, Steppi S, Jobb G, Forster W, Brettske I, Gerber S, Ginhart AW, Gross O, Grumann S, Hermann S, Jost R, Konig A, Liss T, Lussmann R, May M, Nonhoff B, Reichel B, Strehlow R, Stamatakis A, Stuckmann N, Vilbig A, Lenke M, Ludwig T, Bode A, Schleifer K-H (2004) ARB: a software environment for sequence data. Nucleic Acids Res 32:1363-1371

McGinnis S, Madden TL (2004) BLAST: at the core of a powerful and diverse set of sequence analysis tools. Nucleic Acids Res 32:20-25

Muyzer G, Stams AJM (2008) The ecology and biotechnology of sulphate-reducing bacteria. Nat Rev Microbiol 6:441-454

Nübel U, Engelen B, Felske A, Snaidr J, Wieshuber A, Amann RI, Ludwig W, Backhaus H (1996) Sequence heterogeneities of genes encoding 16S rRNAs in Paenibacillus polymyxa detected by temperature gradient gel electrophoresis. J Bacteriol 178:5636-5643

Okabe S, Kindaichi T, Ito T (2005) Fate of 14C-labeled microbial products derived from nitrifying bacteria in autotrophic nitrifying biofilms. Appl Environ Microbiol 71:3987-3994

Oude Elferink SJWH, Rinia HA, Bruins ME, de Vos WM, Stams AJM (1997) Detection and quantification of Desulforhabdus amnigenus in anaerobic granular sludge by dot blot hybridization and PCR amplification. J Appl Microbiol 83:102-110

Pruesse E, Quast C, Knittel K, Fuchs BM, Ludwig W, Peplies J, Glöckner FO (2007) SILVA: a comprehensive online resource for quality checked and aligned ribosomal RNA sequence data compatible with ARB. Nucleic Acids Res 35:7188-7196

Saitou N, Nei M (1987) The neighbor-joining method: a new method for reconstructing phylogenetic trees. Mol Biol Evol 4:406-425
Sanguinetti CJ, Dias Neto E, Simpson AJG (1994) Rapid silver staining and recovery of PCR products separated on polyacrylamide gels. Biotechniques 17:914-921

Schönheit P, Kristjansson JK, Thauer RK (1982) Kinetic mechanism for the ability of sulfate reducers to out-compete methanogens for acetate. Arch Microbiol 132:285-288

Sorokin YI (1966a) Investigation of the structural metabolism of sulfate-reducing bacteria with $C^{14}$. Microbiology 35:967-977

Sorokin YI (1966b) Sources of energy and carbon for biosynthesis in sulfate-reducing bacteria. Microbiology 35:761-766

van Houten BHGW (2006) Microbial aspects of synthesis gas fed bioreactors treating sulfate and metal rich wastewaters. $\mathrm{PhD}$ thesis, Wageningen University, Wageningen

van Houten BHGW, Meulepas RJW, van Doesburg W, Smidt H, Muyzer G, Stams AJM (2009) Desulfovibrio paquesii sp. nov., a hydrogenotrophic sulfate-reducing bacterium isolated from a synthesis-gas-fed bioreactor treating zinc- and sulfate-rich wastewater. Int J Syst Evol Microbiol 59:229-233

van Houten BHGW, Roest K, Tzeneva VA, Dijkman H, Smidt H, Stams AJM (2006) Occurence of methanogenesis during start-up of a full-scale synthesis gas fed reactor treating sulfate and metal rich wastewater. Water Res 40:553-560

van Houten RT, Hulshoff Pol L, Lettinga G (1994) Biological sulfate reduction using gas-lift reactors fed with hydrogen and carbon dioxide as energy and carbon source. Biotechnol Bioeng 44:586-594

van Houten RT, Lettinga G (1994) Biological sulphate reduction with synthesis gas: microbiology and technology. In: Wijffels $\mathrm{RH}$, Buitelaar RM, Bucke C, Tramper J (eds) Progress in biotechnology. Elsevier, Amsterdam, pp 793-799

Weijma J, Gubbels F, Hulshoff Pol L, Stams AJM, Lens P, Lettinga G (2002) Competition for $\mathrm{H}_{2}$ between sulfate reducers, methanogens and homoacetogens in a gas-lift reactor. Water Sci Technol 45:7580 